\title{
VARIATIONS IN THE CHEMICAL COMPOSITION OF HERRING
}

\author{
By John Arnold Lovern, B.Sc., Ph.D. \\ The Torry Research Station, Aberdeen, of the Department of Scientific \\ and Industrial Research \\ and Henry Wood, M.A., Ph.D. \\ The Marine Laboratory of the Fishery Board for Scotland, Aberdeen
}

(Text-figs. I-2)

Of the three main components of the flesh of the herring-protein, fat and water-the last two vary widely with the time of the year, the habitat, and the condition of the fish. There are corresponding variations in the palatability, texture, food value and commercial value. The variations in protein are much smaller, and have no commercial significance.

Channon \& Saby (1932) give a summary of earlier work showing that there is a rise in the fat content of herring muscle before spawning, followed by a fall to a minimum after spawning. These authors studied the fat variations in Manx herring, dealing with liver, mesentery and gonads as well as muscle.

In this study attention has been confined to the body fat, i.e. the fat which lies below the skin and between the muscles. The liver is a small organ of little or no significance as a depot for fat. The fat content of the gonads varies erratically, averaging about $3 \%$. The mesenteric fat constitutes a depot, but one of less importance than the body fat. It is quickly used up during the maturation of the gonads. During winter all herring, irrespective of the seasons at which they spawn, are in a lean condition. In April a perceptible increase takes place in the plankton, which normally becomes abundant in the north-western North Sea in May and June, and leads to a concentration of herring in this region. Throughout May and June the fish feed heavily, their stomachs being packed with food, or showing evidence of recent feeding. During this period fat is rapidly stored in the flesh and around the intestines. In July feeding becomes less intensive. This seems not to be associated entirely with the development of the gonads, for whether this development is taking place or not much less food is found in the stomachs than in those of fish caught in May and June.

Herring showing significant anatomical differences, corresponding with differences in the times of spawning, are held to be of different races. In the Scottish area two distinct races have been established, "spring-spawners", 
spawning in February and March, and "Scottish autumn-spawners", spawning in August and September. The herring of the Scottish Summer Herring Fishery include both these races, and also adults from two other stocks, viz. that which spawns near the Dogger Bank and off the coast of Lincolnshire in September and October and that which gives rise to the Lowestoft and Yarmouth fisheries in October and November and spawns at the eastern entrance to the English Channel in December and January.

In view of the mixed racial character of certain populations of herring and since different races do not spawn at the same season, it is desirable to follow the changes in composition in material biologically as uniform as possible.

Only reasonably fresh herring were used. In almost every sample the dominant groups as regards size and maturity were analysed. In some cases when two groups were present in a sample, whether judged by maturity or size, analyses were made of both. As a rule, however, maturity was regarded as the most important variable, and groups were so selected that analysis was made of herring at all stages from the immature to the spawning or spent condition. Maturity is expressed on the following scale, adopted by the International Council for the Exploration of the Sea:

STAGE I. Sexual organs small; breadth about $2-3 \mathrm{~mm}$.; clear wine or amber colour. No eggs visible to naked eye. (Immature.)

STAGE II. Diameter nearly I cm.; length slightly more than half length of body cavity. Eggs small, unyolked, visible to naked eye. (Developing immatures and recovering spents.)

STAGE III. Organs occupying about half of body cavity. Eggs amber coloured, yolked.

STAGE IV. Organs filling about two-thirds of body cavity. No large transparent eggs.

STAGE V. Organs filling body cavity. Some large transparent eggs may be present.

STAGE VI. Spawning in progress or just imminent. Large transparent eggs.

STAGE VII. Spent. Organs bloodshot. Large residual eggs present.

The analyses (determination of fat, solids and water contents) were carried out on samples consisting of fillets of six or more fish. Removal of the skin led to loss of fat, and in all samples after the first few the skin was left on. After mincing and thorough mixing, a weighed portion of the sample was dried at $105^{\circ} \mathrm{C}$. until sufficiently dry for the fat to be extracted with ether. The residue was then returned to the oven and dried to constant weight, giving the "solids", mainly crude protein.

At first the sexes were examined separately. Table I shows that the variations are very similar in males and females. The maturing females seem to have a slightly lower fat content than the males in July and August, possibly associated with the maturation of the gonads, for in the final phase the ovaries appear to mature more rapidly than the testes. Subsequently the sexes were not separated, males and females being present in the samples in roughly equal proportions.

The greatest variations occur in the water and fat, which vary in inverse 
Table I. Chemical Analysis of Male and Female Herring from the SCOTTISH NoRTH-EAST COAST, I935

\begin{tabular}{|c|c|c|c|c|c|c|c|c|}
\hline & & & & & & & & \\
\hline Date & Maturity & $\underset{\%}{\text { Water }}$ & Solids & $\underset{\%}{\text { Fat }}$ & Maturity & $\underset{\%}{\text { Water }}$ & $\underset{\%}{\text { Solids }}$ & $\bar{F}_{\%}^{\text {Fat }}$ \\
\hline May 2I & I & $68 \cdot 3$ & $2 I \cdot I$ & $10 \cdot 6$ & I & $72 \cdot 7$ & $19 \cdot 2$ & $8 \cdot I$ \\
\hline June 3 & VII-II & $69 \cdot 2$ & 19.0 & II 8 & VII-II & 67.8 & 18.7 & I3. 5 \\
\hline ", & I I & $73 \cdot 6$ & $20 \cdot I$ & $6 \cdot 3$ & I & $72 \cdot 0$ & 19.8 & $8 \cdot 2$ \\
\hline & \{VII-II & $72 \cdot 0$ & 19.3 & $8 \cdot 7$ & II & $72 \cdot 7$ & I9. 5 & $7 \cdot 8$ \\
\hline \# $\quad 12$ & $\mathrm{II}+$ & $62 \cdot 0$ & $19 \cdot 2$ & 18.8 & II + & 66.0 & $19 \cdot 6$ & I 4.4 \\
\hline \# 18 & $\mathrm{II}+$ & 65.6 & I 8.7 & 15.7 & II + & $66 \cdot 2$ & 18.8 & 15.0 \\
\hline \#, 25 & $\mathrm{II}+$ & 64.6 & I $8 \cdot 7$ & I6. 7 & $\mathrm{II}+$ & $60 \cdot 0$ & $20 \cdot 5$ & 19.5 \\
\hline$\Rightarrow 25$ & II & $\int^{\star} 62.5$ & I 8.7 & I 8.8 & II & $62 \cdot 4$ & 18.6 & 19.0 \\
\hline July 2 & & $\begin{array}{r}166 \cdot 2 \\
+65 \cdot 3\end{array}$ & $\begin{array}{l}19 \cdot 2 \\
17 \cdot 2\end{array}$ & $14 \cdot 6$ & & & & \\
\hline & III-IV & 57.5 & $\begin{array}{l}17 \cdot 2 \\
20 \cdot 2\end{array}$ & $\begin{array}{l}21 \cdot 5 \\
22 \cdot 3\end{array}$ & II + & $60 \cdot 4$ & I $8 \cdot I$ & $\begin{array}{l}21.5 \\
18 \cdot 5\end{array}$ \\
\hline Aug. I4 & IV-V & 62.7 & $2 \pi \cdot 4$ & $\begin{array}{l}22.3 \\
15.9\end{array}$ & $\begin{array}{l}\text { III-IV } \\
\text { IV-V }\end{array}$ & 65.3 & $\begin{array}{l}20 \cdot 7 \\
20 \cdot 9\end{array}$ & $\begin{array}{l}18.5 \\
13.8\end{array}$ \\
\hline , 20 & VII & $70 \cdot 6$ & I8. 5 & I0.9 & VII & $70 \cdot 6$ & 19.3 & IO. I \\
\hline , 27 & $\mathrm{~V}$ & 65.6 & $18 \cdot 2$ & $16 \cdot 2$ & IV-V & 69.5 & 18.3 & $12 \cdot 2$ \\
\hline & \{VII & $69 \cdot 7$ & 19.0 & $\mathrm{II} \cdot 3$ & VII & 68.9 & 19.6 & II .5 \\
\hline Dec. 19 & VII & $76 \cdot 8$ & $2 I \cdot 0$ & $2 \cdot 2$ & VII & $75 \cdot 5$ & $2 \mathrm{I} \cdot 3$ & $3 \cdot 2$ \\
\hline
\end{tabular}


ratio. By comparison, the variations in the solids are slight, and appear to be independent of the variations between fat and water. In view of the reciprocal relation between fat and water, discussion may be limited to fat and solids.

\section{FAT}

\section{Immature Herring}

The proportions of the different stocks and races of herring in the population of the north-western North Sea vary from year to year and, within the same season, according to the grounds and time of year. The immature herring of the grounds between Shetland and Peterhead include, however, only the native stocks, i.e. Scottish spring and Scottish autumn spawners (Wood, I936). The immature fish in the region of Shetland belong almost exclusively to spring-spawning stock. From Orkney southwards along the north-east and east coast, sexually immature fish of autumn-spawning stock come into prominence, and normally predominate in the Moray Firth and other shallow regions.

Table II. Chemical Analysis of Flesh of Immature Herring from the Northern and North-Western North Sea. Stage I

\begin{tabular}{|c|c|c|c|c|c|c|}
\hline Area & Date & $\begin{array}{l}\text { Size range } \\
(\mathrm{cm} .)\end{array}$ & $\begin{array}{c}\text { Age } \\
\text { (years) }\end{array}$ & $\underset{\%}{\text { Water }}$ & $\underset{\%}{\text { Solids }}$ & $\begin{array}{l}\text { Fat } \\
\%\end{array}$ \\
\hline Shetland & r936 Apr. 9 & $25 \cdot 7-26 \cdot 9$ & 3 & $74 \cdot 8$ & I9.7 & $5 \cdot 5$ \\
\hline \multirow{3}{*}{ Scottish north-east coast } & May 25 & $25 \cdot 0-26 \cdot 5$ & $3 \frac{1}{4}$ & $7 \mathrm{I} \cdot 3$ & I9.5 & \\
\hline & I935 May 2I & $21 \cdot 8-23 \cdot 5$ & & $70 \cdot 5$ & $20 \cdot 2$ & \\
\hline & I936 June 2 & $22 \cdot 7-23.9$ & $3 \frac{3}{4}$ & $62 \cdot 8$ & 19.2 & I 8. \\
\hline & I935 June 5 & $20 \cdot 5-22 \cdot 7$ & $3 \frac{1}{3}$ & $72 \cdot 8$ & 19.9 & \\
\hline Berwick coast & June II & $21 \cdot 0-22 \cdot 4$ & & $68 \cdot 7$ & $22 \cdot 7$ & \\
\hline \multirow{3}{*}{ Forth } & July 23 & $20 \cdot 9-22 \cdot 2$ & 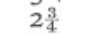 & $64 \cdot 5$ & 19.6 & 15.9 \\
\hline & I936 Jan. I4 & I8.0-20.7 & $2+$ & $73 \cdot 7$ & $19 \cdot 2$ & \\
\hline & $\begin{array}{c}\text { I937 Feb. I6 } \\
\text { Mar. } 9\end{array}$ & $\begin{array}{l}\mathrm{I} 7 \cdot 8-2 \mathrm{I} \cdot \mathrm{I} \\
\mathrm{I} 8 \cdot 0-20 \cdot 0\end{array}$ & $\begin{array}{l}2+ \\
2+\end{array}$ & $\begin{array}{l}73 \cdot 5 \\
75 \cdot 7\end{array}$ & $\begin{array}{l}\text { I9.8 } \\
\text { I9.I }\end{array}$ & $\begin{array}{l}5 \cdot 7 \\
5 \cdot 2\end{array}$ \\
\hline
\end{tabular}

Table II* shows that the lowest values for fat occur in March and April. Fat begins to accumulate in May and reaches its highest value in June and July. It will be seen later that the range of the values is not so great in immature as in adult herring. While the immature fish are able to maintain the higher reserve of fat over the winter, they do not appear to reach the same degree of fatness as adult herring during summer (Tables IV and V); Table II does not, however, include samples of immature herring from Shetland in June and July when they are normally "prime" fish and undoubtedly have a high fat content. Many of the immature fish caught off the Scottish east and north-east coasts in June and July remain immature for another year, and their comparatively rapid growth may not permit the accumulation of a reserve of fat equal to that of adult or nearly adult herring, which require much less food for growth.

* The average age of the fish is given in this and subsequent Tables, although there is no indication that age alone has any appreciable influence on the variations in herring of marketable size. 
Table II also brings out the great variation in fat content from year to year and place to place. The highest values were recorded in the north-eastern area on June 2 I936, while a sample from the same fishing ground on June 5 I935 had the lowest value yet recorded in June.

The data hardly warrant a comparison between herring of the northern areas and those of the more southerly grounds off the Scottish east coast. The records available indicate that the former build up a reserve of fat more quickly than the latter. The differences in the values given in Table II cannot be regarded as constant but they are such as might be expected from the distribution of the organisms on which the herring feeds. These organisms, many of which are derived from regions beyond the North Sea, are patchy in their occurrence, but according to Gibbons (1936) and Gibbons \& Fraser (1937) they are numerous in April and May in the neighbourhood of the Shetland and Orkney Islands, and in May and June are more numerous off the north-east coast of Scotland than off the east and south-east coasts.

\section{Adult Herring of the Northern and North-western North Sea}

Adult here means herring that have spawned and herring that have developed beyond the immature stage and are preparing to spawn at an early date. Examples given here may be accepted as typical of the adult herring caught in the drift-net. The first series of records (Table III) was obtained from catches in Shetland waters where spring-spawning and adult autumnspawning herring sometimes occur together in dense shoals in April and May.

Table III. Analysis of Adult HerRing: Shetland: April-May. Maturities VII ANd II. (Recovering Spents)

$\begin{array}{cc}\text { Date } & \begin{array}{c}\text { Size range } \\ (\mathrm{cm} .)\end{array} \\ \text { I935 Apr. 3 } & 25 \cdot 9-28 \cdot 8 \\ \text { I7 } & 25 \cdot 0-28 \cdot 8 \\ \text { May 22 } & 25 \cdot 0-28 \cdot 6 \\ 26 \cdot 0-29 \cdot 0 \\ \text { I936 Apr. 9 } & 27 \cdot 8-30 \cdot 0 \\ \text { May 27 } & 28 \cdot 8-30 \cdot 3 \\ \text { I } & 27 \cdot 0-29 \cdot 2 \\ \text { 23 } & 26 \cdot 0-28 \cdot 1\end{array}$

$\begin{array}{cc}\begin{array}{c}\text { Age } \\ \text { (years) }\end{array} & \begin{array}{c}\text { Water } \\ \%\end{array} \\ 6 & 76 \cdot 3 \\ 6 & 77 \cdot 5 \\ 5 & 78 \cdot 8 \\ 5 \frac{3}{4} & 76 \cdot 1 \\ 5^{\frac{3}{2}} & 79 \cdot 1 \\ 6+ & 78 \cdot 9 \\ 6+ & 77 \cdot 4 \\ 6 \frac{1}{2} & 73 \cdot 9\end{array}$

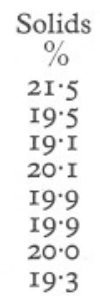

Fat
$\%$
$2 \cdot 2$
$3 \cdot 0$
$2 \cdot 1$
$3 \cdot 8$
$1 \cdot 0$
$1 \cdot 2$
$2 \cdot 6$
$6 \cdot 8$

The percentages of fat are uniformly low, and minimal values are reached in April. During April food normally begins to be abundant in this area, and gives rise to the great concentrations of herring in April and May. In May, when feeding has been going on for some weeks, an increase in the fat content becomes apparent.

The next series (Table IV) refers to adult herring caught off the northeast coast on the grounds normally fished from Wick, Fraserburgh and Peterhead. 
Table IV. Analysis of Adult Herring. North-western NORTH SEA

\begin{tabular}{|c|c|c|c|c|c|c|c|c|c|}
\hline \multicolumn{2}{|l|}{ Date } & Plac & of capture & Maturity & $\begin{array}{c}\text { Size } \\
\text { range } \\
(\mathrm{cm} .)\end{array}$ & $\begin{array}{c}\text { Age } \\
\text { (years) }\end{array}$ & $\begin{array}{c}\text { Water } \\
\%\end{array}$ & $\underset{\%}{\text { Solids }}$ & $\begin{array}{c}\text { Fat } \\
\%\end{array}$ \\
\hline I935 June & 3 & Scottish & north-east coast & VII-II & $23 \cdot 8-27 \cdot 7$ & $5 \frac{1}{4}$ & $68 \cdot 5$ & $\mathrm{I} 8 \cdot 8$ & I $2 \cdot 7$ \\
\hline 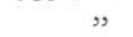 & 5 & & " & $x^{\prime \prime}$ & $22 \cdot 4-24 \cdot 7$ & 4 & $72 \cdot 4$ & I9.4 & \\
\hline ", & 12 & & " & II + & $23.5-24.7$ & $3^{\frac{3}{4}}$ & 64.0 & I9.4 & I6. 6 \\
\hline " & I8 & & " & " & $23 \cdot 6-25 \cdot 7$ & $4 \frac{1}{4}$ & $65 \cdot 0$ & I9.7 & $15{ }^{\circ}$ \\
\hline " & 25 & & " & Ï & $24 \cdot 0-25 \cdot 6$ & $3 \frac{2}{3}$ & $62 \cdot 3$ & I9.6 & I 8. \\
\hline & 25 & & " & II & $22 \cdot 3-25 \cdot 0$ & $3 \frac{2}{3}$ & 63.7 & I8.9 & I7. \\
\hline July & 2 & & " & II + & $23 \cdot \overline{8}-26 \cdot I$ & $4 \frac{3}{4}$ & $60 \cdot 9$ & $17 \cdot 7$ & $2 \mathrm{I}$. \\
\hline , & 23 & & " & III-IV & $24 \cdot 6-27 \cdot 8$ & 5 & $59 \cdot 2$ & $20 \cdot 4$ & 20 \\
\hline Aug. & I4 & & " & IV-V & - & & $64 \cdot 0$ & $2 I \cdot 2$ & I 4 \\
\hline נֶ & 27 & & " & IV-V & $27 \cdot 8-29 \cdot 9$ & $7 \frac{1}{4}$ & $67 \cdot 6$ & $\mathrm{I} 8 \cdot 2$ & $14 \cdot 2$ \\
\hline " & 20 & & " & $\begin{array}{c}\text { VII } \\
\text { (spents) }\end{array}$ & $24 \cdot 7-30 \cdot 5$ & 7 & $70 \cdot 6$ & I8.9 & 10.5 \\
\hline & 27 & Fladen * & " & ” & $25 \cdot 0-29 \cdot 5$ & 6 & $69 \cdot 3$ & $19 \cdot 3$ & II 4 \\
\hline $\begin{array}{l}\text { Oct. } \\
\text { Nov. }\end{array}$ & 28 & Fladen * & & 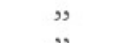 & $\begin{array}{l}27 \cdot 5-29 \cdot I \\
26 \cdot 6-20 \cdot I\end{array}$ & $7+$ & $\begin{array}{l}72 \cdot 6 \\
72 \cdot 4\end{array}$ & $\begin{array}{l}19.4 \\
0.5\end{array}$ & $7 \cdot \mathrm{I}$ \\
\hline & 27 & & & ", & $26 \cdot 7-28.5$ & $7 \frac{1}{2}$ & & 20.1 & \\
\hline Dec. & I9 & Scottish & north-east coast & & $25 \cdot 2-26 \cdot 5$ & $3 \frac{3}{4}$ & $76 \cdot I$ & $2 \mathrm{I} \cdot 2$ & 2 \\
\hline I936 June & 2 & & ", & II & $24 \cdot 0-24 \cdot 9$ & $4 \frac{1}{2}+$ & 63.4 & $19 \cdot 5$ & I7. \\
\hline $\begin{array}{l}\text { July } \\
\text { Nov. }\end{array}$ & $\begin{array}{l}\text { I4 } \\
30\end{array}$ & Fladen* & ” & $\begin{array}{l}\text { IV-V } \\
\text { VII }\end{array}$ & $\begin{array}{l}26 \cdot 0-30 \cdot 0 \\
27 \cdot I-28 \cdot 7\end{array}$ & $\begin{array}{l}5+ \\
83\end{array}$ & $\begin{array}{l}64.5 \\
73 \cdot 2\end{array}$ & $\begin{array}{l}18.9 \\
\text { I9.6 }\end{array}$ & I6. \\
\hline & & & & & & & & & \\
\hline
\end{tabular}

Most of the herring caught off the Scottish north-east coast in June are only at Stage II of maturity. During this month little development of the gonads takes place. There is, however, a rapid increase in the fat content, which reaches its highest value early in July. Thereafter development of the reproductive organs, accompanied by a gradual decline in the fat content, becomes evident. During the later stages in the maturation of the gonads little food is taken, so that the reserves of fat may not be used entirely to meet the demands of the reproductive system.

The analyses for the period July 23-December I9 I935, and for July I4 and November 30 1936, refer exclusively to Scottish autumn-spawners. During these periods the herring were considerably larger than those caught on the same grounds in June, and in this respect they resemble much more closely the samples obtained from Shetland waters in April and May (Table III).

Table IV shows that the fish which spawn near the Scottish east and northeast coast maintain a considerable reserve of fat for some time after spawning by a short period of intensive feeding in August and September. The effect of the decreasing supply of food is apparent in the gradually declining fat content of spent herring from the Fladen ground in October and November; that for December I9 I935, north-east coast, seems abnormally low. 


\section{The Herring of the Fladen Ground}

The Fladen ground, a comparatively deep basin, approximately Ioo miles east-north-east to north-east by east of Aberdeen and beyond the economic range of drifters, is one of the few where herring are caught at the bottom by trawl. The season commences as a rule in the last fortnight of July, and may extend until November or December. During this period important changes take place in the composition of the shoals. In July and August the catches consist mainly of the larger sizes of the stock or stocks which spawn in the late autumn in the area of the Dogger Bank and the southern North Sea, and probably include herring from the East Channel winter-spawning stock. These herring leave the Fladen ground in September for their spawning grounds. Before their departure is completed, herring of entirely different stocks appear, viz. spent fish of Scottish autumn-spawning stock and maturing springspawners, whose gonads are still small in September and October, the majority being only at Stages II and III of maturity. The spent fish have been included in Table IV.

Table $\mathrm{V}$ gives the analysis of herring that spawn in late autumn in the middle and south North Sea, caught, first, on the Fladen ground in July and August, and, later in the year, off the East Anglian coast.

Table V. Analysis of Late Autumn and (Winter?) Spawning HERring. FLADEN AND EAST ANGLIA

\begin{tabular}{|c|c|c|c|c|c|c|c|}
\hline Date & Place of capture & Maturity & $\begin{array}{c}\text { Size } \\
\text { range } \\
\text { (cm.) }\end{array}$ & $\begin{array}{c}\text { Age } \\
\text { (years) }\end{array}$ & $\begin{array}{c}\text { Water } \\
\%\end{array}$ & $\begin{array}{c}\text { Solids } \\
\%\end{array}$ & $\begin{array}{c}\text { Fat } \\
\%\end{array}$ \\
\hline 935 July I8 & Fladen & II & $24 \cdot 8-26 \cdot 7$ & $4^{\frac{3}{4}}$ & $60 \cdot 3$ & $18 \cdot 0$ & $2 \mathrm{I} \cdot 7$ \\
\hline $\begin{array}{l}\text { Aug. I9 } \\
936 \text { Oct. } 6\end{array}$ & & IV-V & $27 \cdot 6-29 \cdot 4$ & $7+$ & $66 \cdot 4$ & 17.7 & 15.9 \\
\hline 935 , 23 & $\begin{array}{l}\text { Dogger } \\
\text { Off Lowestoft }\end{array}$ & $"$ & $\begin{array}{l}27 \cdot 0-29 \cdot 0 \\
23 \cdot 7-24 \cdot 7\end{array}$ & - & $\begin{array}{l}68 \cdot 3 \\
67 \cdot 7\end{array}$ & $\begin{array}{l}18 \cdot 0 \\
18 \cdot 3\end{array}$ & $\begin{array}{l}13.7 \\
\text { I4.0 }\end{array}$ \\
\hline & , & ", & $26 \cdot 6-28 \cdot 7$ & $7 \frac{3}{4}$ & 67.6 & I $8 \cdot 3$ & I $4 \cdot I$ \\
\hline
\end{tabular}

Those caught on the Fladen ground in July at the earlier stages of sexual development have a high fat content. In August the more developed fish show a considerable decline, although fatter than herring of corresponding maturity caught at the same time on the drift-net grounds. Thus, this component of the Fladen population has a large store of fat on its departure to spawn in the middle and southern North Sea. The samples caught off Lowestoft show that the reserve may be maintained until October and November, provided that spawning has not taken place.

Spring-spawners are normally abundant between Shetland and the west coast of Norway in April and May, and around Shetland from May until about mid-July. From these sources come the spring-spawners which begin to assemble on the Fladen ground in September. Coming from an area where food is abundant in spring, they must have accumulated fat at least as fast as the fish of the June series in Table IV. 


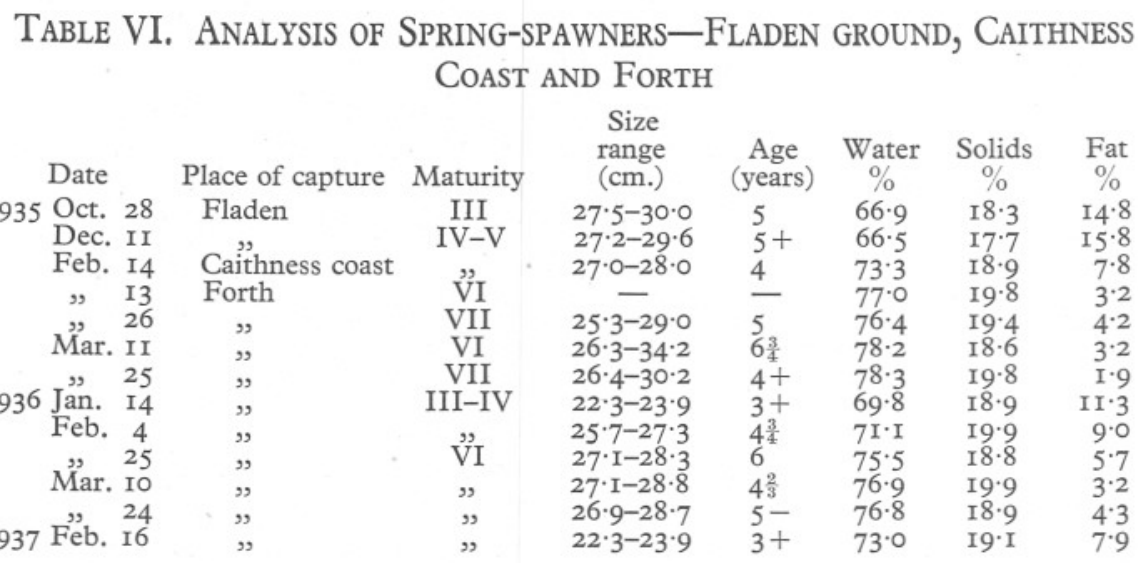

Table VI refers only to spring-spawning herring, although it is not implied that all belong to the same spawning community. Racial analysis was carried out on all samples, and evidence was found that the sample of February I4 I935 from the Caithness coast and the sample of March 25 I 935 from the Forth were identical with the spring-spawners from the Fladen ground the previous autumn. The series gives some indication of the rate at which the reserves of fat are expended. The maturing spring-spawners caught on the Fladen ground in October and December have values ranging from $\mathrm{I} 4.8$ to I5. $8 \%$. A sample of maturing herring (maturity III-IV) from the Forth, caught on January I4 I936, gives a relatively high value of $11 \cdot 3 \%$, and another sample of the same maturity, caught on February 4, gives a value of $9.0 \%$. A sample at Stage IV, obtained in February 1937, gives a value of $7.9 \%$, while the figure for that from the Caithness coast, which was slightly more mature, is $7.8 \%$. Apart from these relatively high values, the other samples caught in February and March, and consisting of spawning or spent fish, give low values ranging from $\mathrm{I} \cdot 9$ to $5 \cdot 7 \%$. Thus, there is a fairly rapid decline in the fat content, corresponding with the rapid final phase in the development of the gonads.

Tables V and VI make it clear that all the herring, other than spent fish, caught in autumn and late autumn on the Fladen ground, have a high fat content which is fairly well maintained until a short time before spawning.

\section{Clyde Spring-spawners}

In recent years the summer and autumn catches within the Clyde estuary have consisted almost exclusively of small immature herring or herring maturing for the first time. On the other hand, the spawning shoals caught in spring are extremely variable in size and age, including small fish from the estuary and older and much larger fish from sources outside the estuary. The data for this region are given in Table VII. 


\section{Table VII. Analysis of Clyde Herring}

\begin{tabular}{|c|c|c|c|c|c|c|}
\hline Date & Maturity & $\begin{array}{c}\text { Size } \\
\text { range } \\
\text { (cm.) }\end{array}$ & $\begin{array}{c}\text { Age } \\
\text { (years) }\end{array}$ & $\underset{\%}{\text { Water }}$ & $\underset{\%}{\text { Solids }}$ & $\begin{array}{c}\text { Fat } \\
\%\end{array}$ \\
\hline I935 Feb. 7 & $\mathrm{~V}$ & $?$ & $?$ & $75 \cdot 2$ & I8.9 & 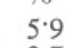 \\
\hline Mar 7 & $\mathrm{~V}-\mathrm{VI}$ & $25 \cdot 5-31 \cdot 9$ & ? & $76 \cdot 5$ & $19 \cdot 8$ & \\
\hline Mar. 6 & VI & $26 \cdot 7-28 \cdot 9$ & 4 & $78 \cdot 3$ & 18.8 & \\
\hline July 3 & I & $20 \cdot 6-22 \cdot 3$ & $2 \frac{1}{4}$ & $59 \cdot 4$ & $20 \cdot 0$ & 20 \\
\hline Sept. 5 & & $\mathrm{I} 9 \cdot 8-2 \mathrm{I} \cdot 2$ & $2 \frac{1}{2}$ & $59 \cdot 2$ & $20 \cdot 4$ & \\
\hline 5 & II-III & $22 \cdot 9-24 \cdot 3$ & $2 \frac{1}{2}$ & $60 \cdot 0$ & $2 \mathrm{I} \cdot 2$ & I8 \\
\hline 1936 Jan. 2I & III-IV & $22 \cdot 3-24 \cdot 9$ & $2 \frac{3}{4}$ & $69 \cdot 6$ & $18 \cdot 0$ & \\
\hline Feb. 4 & & $23 \cdot \mathrm{I}-24 \cdot 7$ & $3-$ & $72 \cdot 0$ & I8. 4 & \\
\hline , 12 & $\mathrm{~V}-\mathrm{VI}$ & $28.0-29 \cdot 8$ & 4 & $7 \mathrm{I} \cdot 9$ & I9.7 & \\
\hline Mar. I6 & VI & $23 \cdot 3-24 \cdot 7$ & 3 & $76 \cdot 1$ & 18.8 & \\
\hline
\end{tabular}

When spawning is completed in February and March, the spent shoals leave the estuary and rarely return until the approach of the next spawning. Thus, it is impossible to observe the rate at which the spent adults recover. In spite of the lack of records between March and July, it is apparent that the Clyde herring accumulate fat rapidly during early summer. The high figure of $20.6 \%$ recorded on July 3 is maintained until September, when a slight decline is seen in herring whose gonads have begun to develop. Few of the estuarine stock reach Stage IV of maturity before January, so that there is every reason to believe that the reserves of fat are well maintained until the end of the year. In January and February, with the acceleration in maturation and a declining supply of food, the stored fat begins to be used up, and at the spawning season reaches low values, which, however, are rarely so low as in the spring-spawning herring of the Forth.

\section{Northern North Sea Spring-spawners}

During winter, more particularly in February and March, shoals of large herring concentrate along the continental slope, and are frequently caught by trawlers in the region of the Viking Bank, a few miles off the north and northwest coasts of Shetland and in the neighbourhood of the Flannan Islands, which lie in the Atlantic to the west of Lewis. These herring differ in important respects from North Sea herring. As a rule they are larger and older, and are rarely found near the coasts until spawning time. The analysis of the few samples examined is given in Table VIII.

\section{Table ViII. Analysis of Adult Herring of the Atlantic Slope}

\begin{tabular}{|c|c|c|c|c|c|c|c|}
\hline Date & Place of capture & Maturity & $\begin{array}{c}\text { Size } \\
\text { range } \\
(\mathrm{cm} .)\end{array}$ & $\begin{array}{c}\text { Age } \\
\text { (years) }\end{array}$ & $\begin{array}{c}\text { Water } \\
\%\end{array}$ & $\underset{\%}{\text { Solids }}$ & $\begin{array}{c}\text { Fat } \\
\%\end{array}$ \\
\hline I935 Mar. I2 & Shetland & VI & $\begin{array}{l}32 \cdot 5-35 \cdot 9 \\
30 \cdot 0-37 \cdot 2\end{array}$ & $\begin{array}{r}\mathrm{I} 2 \\
8\end{array}$ & $74 \cdot 4$ & $\begin{array}{l}17.7 \\
18.4\end{array}$ & $\begin{array}{r}7 \cdot 9 \\
7.6\end{array}$ \\
\hline I936 Feb. 25 & " & V-VI & $33 \cdot 4-35 \cdot 2$ & $\begin{array}{l}0 \\
\text { II } 1 \frac{1}{4}\end{array}$ & $\begin{array}{l}74.0 \\
63 \cdot 1\end{array}$ & $\begin{array}{l}18.4 \\
17.3\end{array}$ & I4 \\
\hline I937 Feb. I8 & & IV-V & $32 \cdot 9-34 \cdot 5$ & $9 \frac{1}{2}$ & $6 \ddot{8} \cdot 7$ & 18.7 & $12 \cdot 6$ \\
\hline Apr. 20 & North Ireland & VII & $32 \cdot 5-33 \cdot 9$ & 7 & $75 \cdot 5$ & $20 \cdot 0$ & $4 \cdot 5$ \\
\hline
\end{tabular}


The series in Table VIII has the highest values for fat yet recorded in February and March. Some loss may be expected before food is available in abundance in April and May*; the sample from the north coast of Ireland on April 20, I937 gives a value of $4.5 \%$. Nevertheless, it appears that the reserves of these herring are not so severely taxed during winter as those of the smaller North Sea stocks.

Fig. I gives the approximate fat content of the chief North Sea stocks throughout the greater part of the year. It is assumed that fat accumulates more or less uniformly in all stocks in May and June. How long a high fat content is retained after the maximum has been reached in July largely depends on when spawning takes place. The breaks in the curves, joined by dotted lines, require explanation. At these periods both spawning (or ripe)

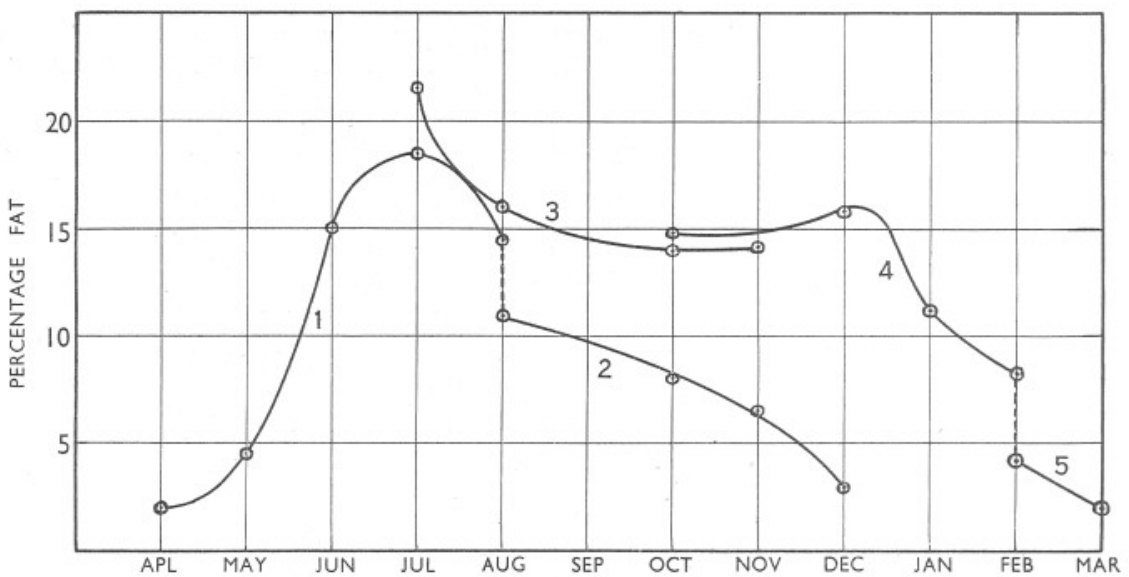

Fig. I. Fat content of North Sea herring (adult stages). I, Scottish autumn spawners; 2, Scottish autumn spents; 3, middle and southern North Sea spawners; 4, Scottish spring spawners; 5 , Scottish spring spents.

and spent fish occurred in the catches. The spawning fish gave the higher values and the spent fish the lower. After these periods only spent fish were obtained. There is evidently a rapid loss of fat during spawning.

\section{Solids}

The range in the percentage of solids recorded here is from $17 \cdot 3$ to $22 \cdot 7$; the variation recorded by one of us (J. A. L.) for a greater number of samples (I3I) is from I6.I to 22.7 . In Fig. 2 the percentages found in these I3I samples are plotted against the frequency (number of samples) of their occurrence. The range 18-20\% covers most of the samples.

Variations in the solids content must almost certainly be ascribed to variations in protein content, since no other constituent of the solids is present in a sufficiently large proportion to account for them. The protein in fish can

* Table III shows that the lowest values occur in April. 
vary with the intensity of protein feeding, as shown by McCay \& Tunison (I936) for trout; the variations they induced experimentally were of about the same order as those found in the solids of the herring.

If the variations in herring are due to differences in intensity of feeding, a high solids content should appear at about the same time as the maximal fat content. Further, minimal values for solids would be expected in ripening fish, which as a rule take little food, and still more so in spent fish.* In the Clyde herring such a relationship is apparent. The highest values for this region were found in young fish, caught in July and September, which were either immature or beginning to mature for the first time. The values during or immediately prior to the spawning were relatively low.

Table IV shows, however, that the solids may have a high value in both

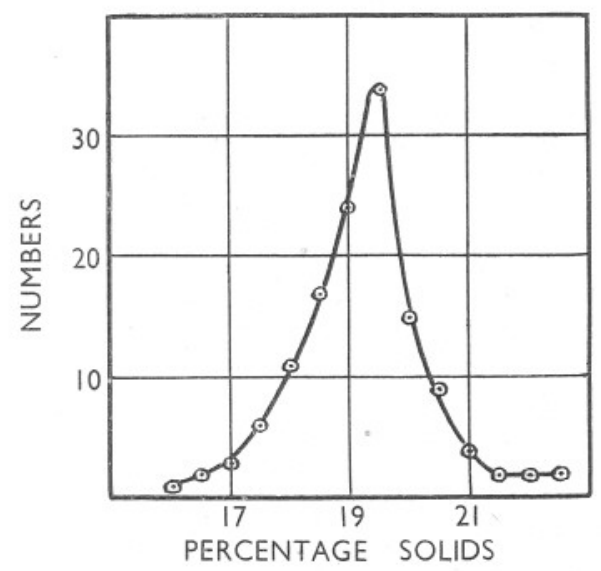

Fig. 2. Frequencies of solids contents (\%) in herring fillets.

maturing and spent fish. In fact, it might appear from the tables as a whole that the solids vary erratically. Actually, the variations are probably the net result of several factors, including the feeding and spawning cycles. Race, however, appears to be at least equally important. For example, Table V shows that the herring which spawn in the middle or southern North Sea in the late autumn or winter have relatively low values for solids, as have also the samples caught off Lowestoft in October and November. Moreover, Table VI shows that the spring-spawners caught on the Fladen ground in October and December show relatively low values. These spring-spawners have been identified with the Shetland spring-spawners (Wood, I937), and Table VIII shows that the large oceanic spring-spawners caught in the neighbourhood of the Viking Bank and off Shetland show the lowest values for solids of all the series detailed. By comparison the spring-spawners of the Firth of Clyde and those caught off the north-west of Ireland in April 1937

* Especially in view of the large quantities of protein transferred to the maturing gonads. 
show significantly higher values. The herring from the Scottish north-east coast (Table IV) show a relatively wide range in the solids, which cannot be explained entirely by the mixed composition of the population. The very low value obtained for the sample of July 2 I935 suggests that it belonged either to Shetland spring-spawning or middle or southern North Sea spawning stocks, rather than to Scottish autumn-spawning stock; racial analysis definitely ruled out the possibility of it being of Shetland spring-spawning stock, and indicated that the racial characters were nearer to Dogger Bank or middle North Sea spawning stock than to Scottish autumn-spawners.

The smooth shape of the curve in Fig. 2, and the absence of more than one maximum, suggests that racial peculiarities in the solids content cannot be sharply defined and must overlap considerably. This is, perhaps, what would be expected by analogy with other racial characteristics. The masking effect of the spawning and feeding cycles must also be borne in mind.

It is inadvisable as yet to draw any further conclusions from the variations in solids contents; more detailed investigations are necessary for the elucidation of their causes.

\section{SUMMARY}

A study has been made of the seasonal and other variations in the contents of fat, water and total solids (other than fat) of the flesh of herring. The herring studied were mainly from Scottish and Shetland waters.

Various races of herring, differing anatomically and with different spawning seasons, are considered separately. For each, the observed changes in chemical composition are considered in relation to the season of the year and the feeding and spawning cycles of the fish.

During May and June there is a rapid rise in the fat content of herring (demonstrated for some races and inferred for the rest). This is correlated with a period of intensive feeding. After the attainment of maximal values in July there is a fall to minimal values in April. The rapidity of the fall depends on the spawning season, a relatively high fat content being maintained until spawning takes place. During spawning there is a rapid fall in the fat content, due, in part at least, to cessation of feeding.

The variations in the solids content of herring are of a smaller order. The causes of them are not clear, but probably several factors are involved, including the feeding and spawning cycles and race.

The water content varies inversely with the fat content, and is not separately considered. 


\section{REFERENCES}

Channon, H. J. \& SABY, M. K. E., I932. Fat metabolism of the herring. I. A preliminary survey. Biochem. Fourn., Vol. 26, pp. $2021-34$.

GibBons, S. G., I936. Calanus finmarchicus and other copepods in Scottish waters in 1933. Fisheries, Scotland, Sci. Invest., No. 2.

GibBons, S. G. \& Fraser, J. H., 1937. Experiments with the "Hardy" plankton indicator in Scottish waters. I. Fourn. Cons. Int. Expl. Mer, Vol. xII, pp. 45-50.

McCay, C. M. \& Tunison, A. V., I936. Cortland Hatchery Report, No. 5. (N.Y. State Cons. Dept., U.S. Bur. of Fish. and Cornell Univ.)

Wood, H., I936. Race investigations of the herring population of Scottish waters. Fisheries, Scotland, Sci. Invest., No. 3.

1937. Movements of herring in the northern North Sea. Fisheries, Scotland, Sci. Invest., No. 3. 